\title{
International tourists' perceptions on spice markets: A guideline to introduce spice market concept into Sri Lankan context
}

\author{
I. C. Hettiarachchi ${ }^{1 *}$, D. A. M. De Silva ${ }^{2}$, M. Esham ${ }^{3}$ \\ Received: $19^{\text {th }}$ November 2020 / Accepted: 13 th July 2021
}

\begin{abstract}
Purpose: The possibilities of syndicating spice and tourism industries to exploit its fullest potentials to achieve wider benefits have been rarely discussed and such attempts have been rarely made by previous scholars. In such an environment, our main focus was to introduce the "spice market concept" to the Sri Lankan context to strengthen the weak link that exists between the two industries.
\end{abstract}

Research Method: First phase of the study was designed to explore issues associated and strategies adopted by Cochin, Turkey and Dubai spice markets through the analysis of 715 customer views. Second phase of the study was shaped by the insights obtained from the key industry informants/experts through interviews and focus group discussions. Both qualitative and quantitative techniques were instrumental in data analysis.

Findings: Product strategy varied from raw spices, organic spices, fair trade spices to high end value additions like nutraceuticals. Cochin and Turkey spice markets were recognized as reliable sources of high-quality spices with the consensus of $80 \%$ and $66.7 \%$ of the reviewers. Women cooperatives, Arabian, Egyptian, Indian, Iranian, and Syrian marketing channels were the focal sources of spices. Competitive and discount pricing strategies were common to all studied market places. Promotional strategies varied from on-site special promotions to e-marketing. Ethical, customer friendly, caring and trustworthy services were main customer demands. Bentota, Hikkaduwa and Kandy would be promising locations to establish spice markets.

Limitations: Lack of firsthand experience on Turkey and Dubai spice markets was a constraint during the study.

Originality/value:If implemented in the planned way, the proposed spice market concept could generate a momentous contribution to the country's socio-economic development through the diversification of the tourism and spice industries.

Keywords: international tourist, spice market, content analysis, marketing mix, strategies

\section{INTRODUCTION}

Undoubtedly, "spices" can be considered as the queen of ancient commerce. This valuable merchandise not only created the earliest evolution of trade but also trade wars over spice lands which lasted for about 200 years and piracies of ships filled with rich cargoes of spices especially off the coast of Portugal. The global seasoning and spice market size was valued at USD 15.09 billion in 2017 and it is forecasted to grow up to USD 19.57 billion by the end of 2024 at a Compound Annual Growth
Rate (CAGR) of $4.59 \%$ (Global Seasonings and Spices Market Report, 2019). This incremental growth could be triggered by the growing demand for certified organic spices and Fairtrade spices particularly from health-conscious consumers with high disposable income, emerging trends in consuming spicy fast foods, rising inclination towards ready to drink

Department of Agribusiness Management,

Faculty of Agricu tural Sciences, Sabaragamuwa University of Sri Lanka, P.O. Box 02, Belihuloya

isuru.susl@gmail.com

iD https://orcid.org/0000-0001-9503-4235 
beverages with spice origin, growing tendency among Europeans to travel Asian destinations, shifting food habits more towards spice rich Asian cuisines and increasing industrial uses of spices in the fields of medicine, hospitality, cosmetics, lifestyle, and alcohol (Hettiarachchi et al., 2020).

SAPPTA(2015) recognizes Sri Lanka as a global supply source of high-quality cinnamon, pepper, cloves, cardamoms, nutmeg, mace, and vanilla. According to the Export Development Board (2017), being hold the $9^{\text {th }}$ position of the world's largest spice exporters list and the topmost position of the world's largest "true cinnamon" exporters list, Sri Lanka export around 30 thousand tons of spices; mainly cinnamon, clove, cardamom, and nutmeg, to more than 50 countries in the world. On the other hand, withdrawal of the travel bans and security alerts after the civil war which spanned over 30 years, made Sri Lanka a holiday destination waiting to be discovered and celebrated. This was hugely supported by the declarations made by reputed travel websites and magazines as one of the world's best emerging tourist destinations. It is well evident by the global recognitions awarded to Sri Lanka by the votes of the world's top travel influencers, bloggers, and vloggers during the period of 2018-2019; such as, "The Best Travel Destination in 2019" by Lonely Planet's Best in Travel Awards, "The Top Travel Destination in Asian Continent for 2019" by Travel Lemming Reader Awards and "Third Best Place to Travel in 2019" by i-escape Travel Website Awards. Thus, Sri Lanka was rated on top of "The Cool List of 2018" by National Geographic Traveler and honored by the People's Daily newspaper of China as the "Top Global Safety Destination for Women Travelers in 2018". According to the statistical report published by the Sri Lanka Tourism Development Authority (2018), the travel and tourism industry holds the third place of the largest foreign exchange earners list in 2018 by pumping $712,027.3$ million rupees (15.9\% of total foreign exchange earnings) to the country's economy providing services to 2.33 million international tourists who spend an average 10.8 days duration of stay. The number of occupations and self-employment opportunities generated by the travel and tourism industry during the period concerned was recorded as 388,487; 169,003 direct and 219,484 indirect, and the direct contribution made to the GDP was recorded as 4.9\% (Central Bank Annual Report, 2018).

However, the merging possibilities of spice and tourism industries to exploit their fullest potentials to achieve more comprehensive benefits have been rarely discussed, and such attempts have been rarely made. At the moment, the two industries are linked only by the spice garden-based agri-tourism ventures. According to Malkanthi (2017), although the visitor awareness on tropical spices is high, their knowledge on the concept of "spice tourism" is low. Barbieri (2010), Prabhudesai and Kunde (2011), and Schilling et al. (2012) define spice tourism as a subsector of agritourism in which the visitors gain knowledge and experience on a variety of spices/herbs, their value-added forms, and spice/herbs-based services (restaurants offering spicy cuisines, spa \& body massage, ayurvedic therapy treatments, etc.) while roaming around spice/ herb plantations, markets, and service facilities. Mahaliyanaarachchi (2016), describes agritourism as a good source of foreign exchange earnings for many developing countries with high rates of unemployment, and heavy indebtedness to balance their payments deficits and settle foreign debts. Spice tourism is a viable alternative for spice farming communities to sustain their income while mitigating the adverse effects of the climatic change and the global price reductions (Che et al., 2005). As argued by Mac (2011), spice garden-based agro-tourism opportunities are still at their initial stage and only a few such destinations are operating with minimal facilities and services. This is in line with the findings highlighted by Bandara (2016); out of 13 attributes of spice gardens, there were no attributes with which the tourists were satisfied. Malkanthi and Routry (2012) proposed the spice tourism segment as one of the subsectors in the Sri Lankan tourism industry that has gone unnoticed by the authorities though it carries an enormous development potential.

In such an environment, our main focus was to 
introduce the "spice market concept" to the Sri Lankan context to strengthen the weak link that exists between the two industries. The specific objectives of this study were: (1) to identify the strategies adopted by the governing authorities and key actors of the Cochin, Turkey, and Dubai spice markets concerning the marketing mix elements, (2) to select appropriate location/s to establish the proposed spice market/s, and (3) to develop a set of guidelines and strategies to carry the spice market concept forward.

The significance of the study can be discussed from theoretical and practical perspectives. Since a very limited number of researches have been carried out to identify the potentials and benefits of amalgamating spice and tourism industries, particularly at the domestic level, findings of this research will be important from a theoretical point of view, not only to fill the gaps of existing literature but also as a reference point to execute future research studies prolifically. In a context where tourism and spice industries are in good shape to make a momentous contribution to the country's socio-economic development, the systematic implementation of the proposed unorthodox strategies is supposed to make the spice market concept a reality, generating thousands of direct and indirect employment opportunities and opening up new gateways to novel income sources for all the parties involved.

\section{MATERIALS AND METHODS}

The design of the study can be described as exploratory ex post facto, as it has been designed to explore issues and strategies; perceived and actual, associated with three spice markets; Cochin, Turkey, and Dubai, through its structure, functions, roles as well as the actors. According to Hudson et al. (2013), Xie et al. (2016), and Mate et al. (2019), there has been an increasing attention by academics on the use of review sites and social media sites with a specific focus on consumer behaviors and expectations. Going in line with this, the first phase of the study involved collecting and analyzing customer reviews available on the respective pages of the "TripAdvisor website", which is administered by an American travel and restaurant website company; TripAdvisor Incorporation.

TripAdvisorwebsitewasconsidered fortheonline survey purely based on the credibility of the site as an independent, evaluative, representative, nonpunitive and reliable information provider (Huang et al., 2010; Gonzalez et al., 2013; Zhang et al., 2014). TripAdvisor has employed not only a strong verification process which considers the IP address and email address of the reviewer but also tries to detect the use of obscene or abusive language and any suspicious patterns of publishing comments to minimize the possibility of publishing unsubstantiated anonymous reviews on any tourist attraction or travel-related business on their web site. Further, the community of users has been given the right to report any suspicious content, which is then examined by the TripAdvisor staff to ensure the credibility of published information (Stagg, 2011 and Hall, 2011).

Sampling frame for "Misir Carsisi" (Turkey spice bazaar) consists with 3615 traveler reviews published during the period of December 2006 to April 2019. Reviews were available in 22 languages as below; English (1966), Spanish (298), Chinese (263), Portuguese (223), Russian (223), Italian (222), Japanese (163), Chinese (148), French (126), Turkish (123), German (88), Arabic (50), Greek (34), Dutch (22), Swedish (18), Indonesian (9), Danish (8), Korean (8), Norwegian (4), Polish (3), Thai (3), Czech (2). Key word search was employed to extract 436 reviews which elaborate the strengths and weaknesses of the location. Among them 100 descriptive and comprehensive reviews published in English language during the period of January 2015 to April 2019 were taken into sample using judgmental/purposive sampling technique.

Sampling frame for "Dubai spice souk" consists with 1580 traveler reviews published during the period of October 2010 to April 2019. Reviews were available in 22 languages as below; English (824), German (150), Italian (145), Chinese (192), Portuguese (97), Japanese (88), French (76), Spanish (71), Russian (33), Dutch (23), Swedish (11), Polish (8), Danish (7), 
Norwegian (7), Korean (6), Turkish (4), Arabic (3), Czech (3), Hungarian (3), Greek (2), Finnish (1). Among them 196 reviews elaborating the strengths and weaknesses of the location were extracted using key word search. Judgmental/ purposive sampling technique was employed to select 80 descriptive and comprehensive reviews published in English language during the period of January 2015 to April 2019 as sampling elements.

Sampling frame for "Cochin spice market" consists of 83 traveler reviews published during the period of October 2010 to February 2019. Reviews were available in 8 languages as below; English (68), French (5), German (5), Arabic (1), Italian (1), Japanese (1), Portuguese (1), Spanish (1). Due to the unavailability of a large number of reviews from which a sample could be drawn as in the cases of "Misir Carsisi" and "Dubai spice souk", all 68 comments published from January 2015 to April 2019 were considered to the sample providing a true measure of the population with a minimum sampling error. Further, the research team conducted a visit to India during the period of $11^{\text {th }}-16^{\text {th }}$ November 2017 to study the Cochin spice market and to understand the way it functions through personal observations. In-depth interviews were conducted with the officials of the Indian Spice Board (ISB) and Indian Export Development Board (IEDB) to reveal high profile insights. Also, discussions with salesforce/distribution partners, purchase of competitive products, field, and factory visits, and visits to trade shows/exhibitions were conducted during the visit to collect primary industry intelligence.

As elaborated in figure 01 , no significant differences were recorded for the destinationwise overall traveler ratings and traveler ratings associated with the respective samples. Hence, the chosen 248 reviews could be considered as the best fits for the study's purpose not only to represent the studied populations but also to generalize the findings to respective populations. Figure 02 illustrates the distribution of selected reviews over time for Turkey, Dubai, and Cochin spice markets.

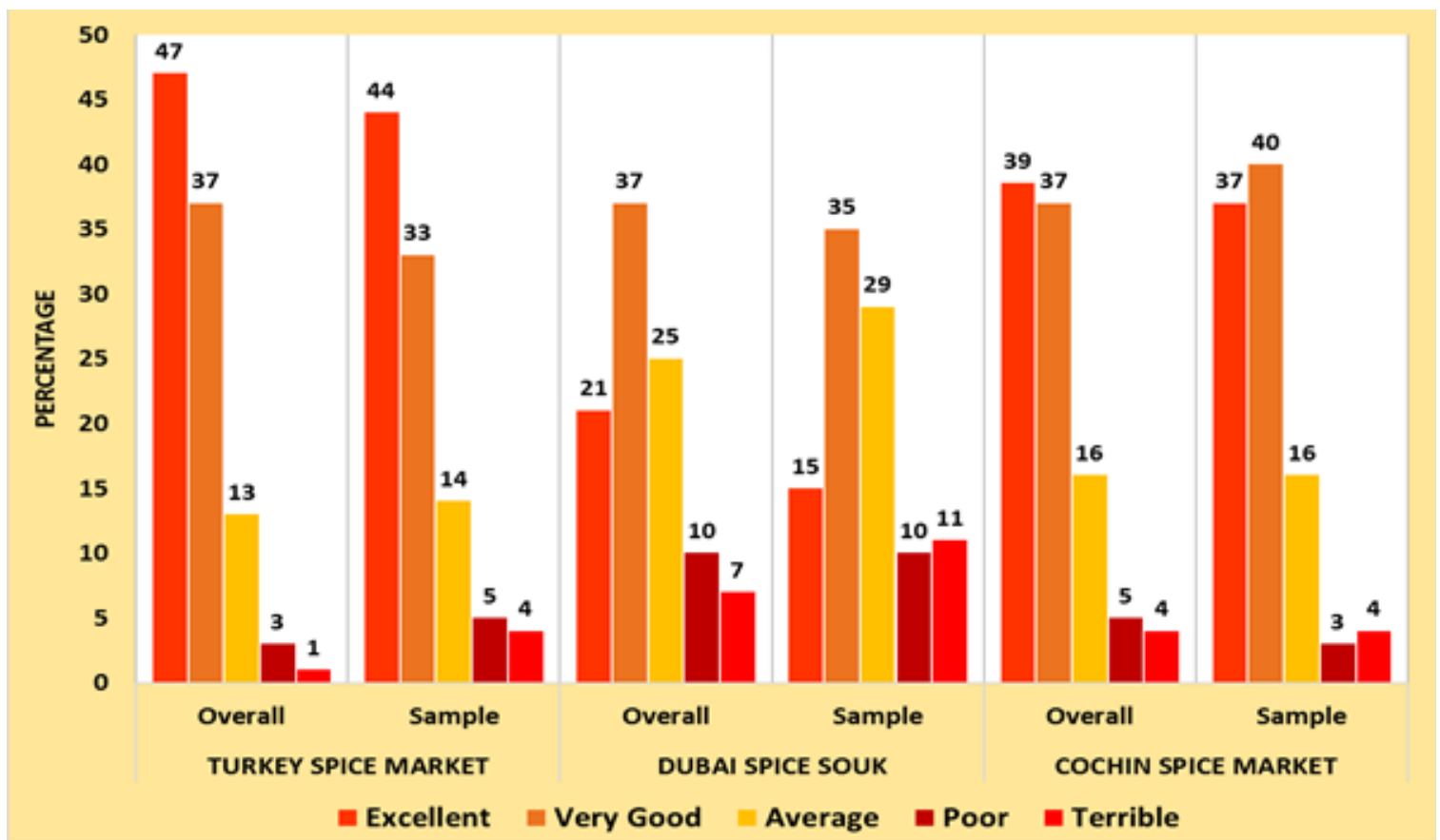

Figure 01. Traveler rating comparison 


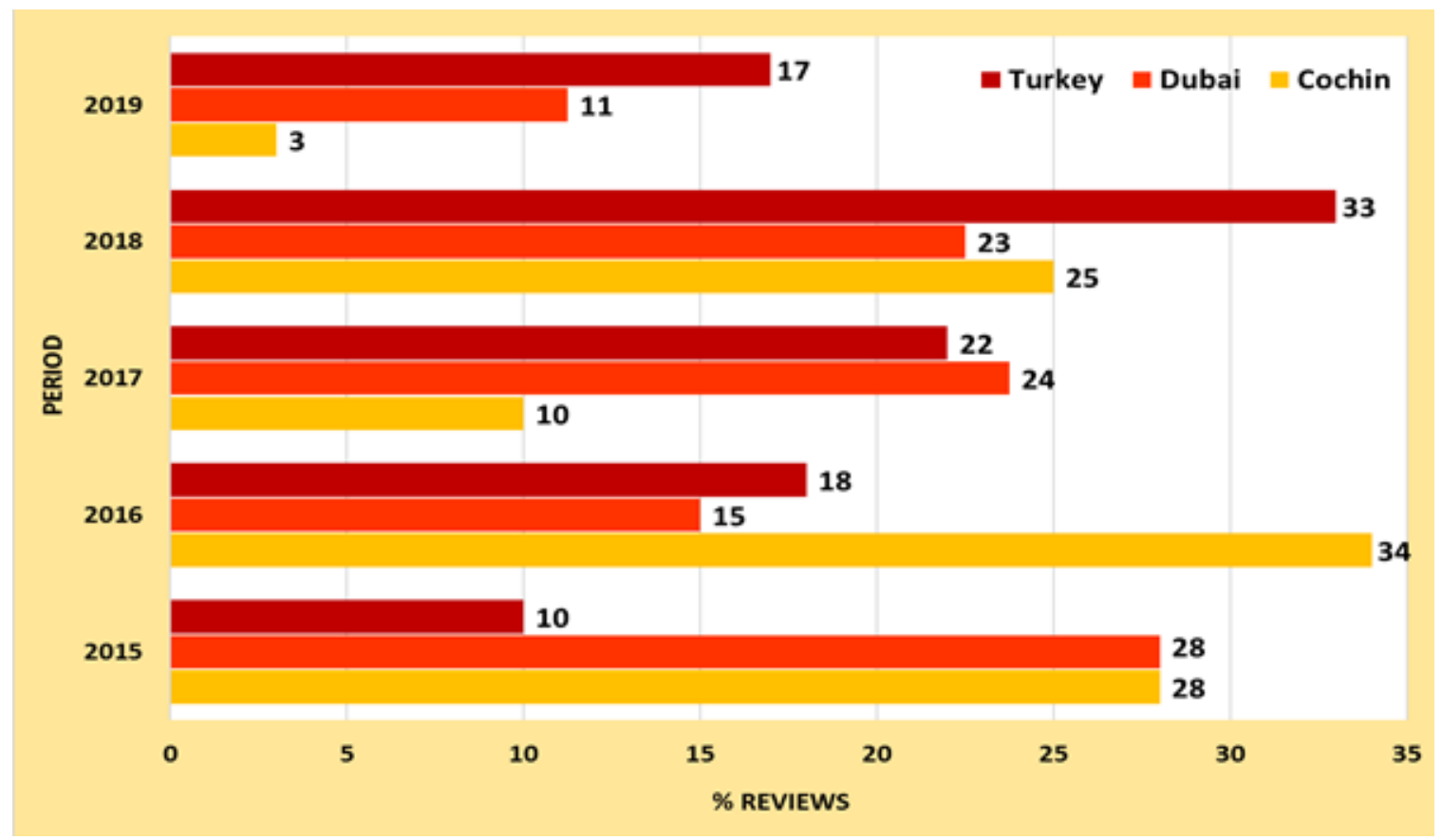

Figure 02. Distribution of reviews over time

The second phase of the study was achieved by the insights obtained from the key industry informants/experts through interviews and focus group discussions. They were further supported by the secondary data obtained through Central Bank Annual Reports, reports published by the Department of Export Agriculture, Industry capability reports published by the Export Development Board, progress reports published by the Sri Lanka Tourism Development Authority and Association of Small and Medium Enterprises in Tourism Sri Lanka. With data spread across many different formats, both qualitative and quantitative techniques were instrumental in data analysis. NVivo 10 qualitative data analysis software was utilized to analyze unstructured traveler reviews, interviews, and focus groups. Units of observation were first categorized into eight pre-design node structures/themes: a) traveler perceptions on products, b) prices, c) place, d) promotions, e) people, f) opportunities, g) challenges, and h) proposed strategies, using the deductive coding approach. Coding queries were then applied to test traveler perceptions and expert suggestions and to explore trends available in source materials. Matrix coding queries employed to compare respondent's comments based on three demographic attributes (gender, region, and traveler type). SPSS Statistics 23 software package facilitates the Chi-square test (at 95\% confidence interval) to evaluate the association between the identified demographic attributes of visitors and their willingness to visit spice markets, purchase spices/non-spice products, and enjoy spice-based services. Guidelines and strategies were developed to establish "spice market/s" at the identified tourist hubs of the country, proposing an ideal model to carry the idea forward within the cultural, economic, and environmental framework of Sri Lanka to achieve greater benefits from Ceylon spices and tourism industries.

\section{RESULTS AND DISCUSSION}

\section{Descriptive statistics}

Descriptive statistics were employed to analyze the visitor profiles. Figure 03 presents the gender distribution of the three samples. More than half of the respondents who represented the Cochin and Turkey spice markets were males and the respective percentages were $57 \%$ and $52 \%$. The majority of the respondents represented the Dubai spice souk were females (53\%) and comparatively a smaller number of male respondents. The gender of $18 \%$ of the 
respondents remained anonymous for Dubai spice souk and the respective values for Cochin and Turkey spice markets recorded as $13 \%$ and $12 \%$. This is partially in line with the findings of Malkanthi (2017), where she observed a similar proportion of male and female visitors at the spice tourism ventures.

Selected reviews were categorized into six different regions; African, American, Asian, European, Middle East, and Oceanic, following the United Nations country grouping to comprehend regional level perceptions on considered variables. The majority of the selected comments (53\%) for the Cochin spice market were recorded from Asian travelers and it was followed mainly by the comments made by Europeans (22\%) and American (14\%) travelers. Samples of Turkey and Dubai spice souks dominated by European travelers; 35 and 41 percent respectively, while the second and third positions being shared by American and Asian travelers. Across samples, the lowest views were recorded from African, Middle East, and Oceanic regions. Distribution of travelers by region for the selected samples is depicted in figure 04 .

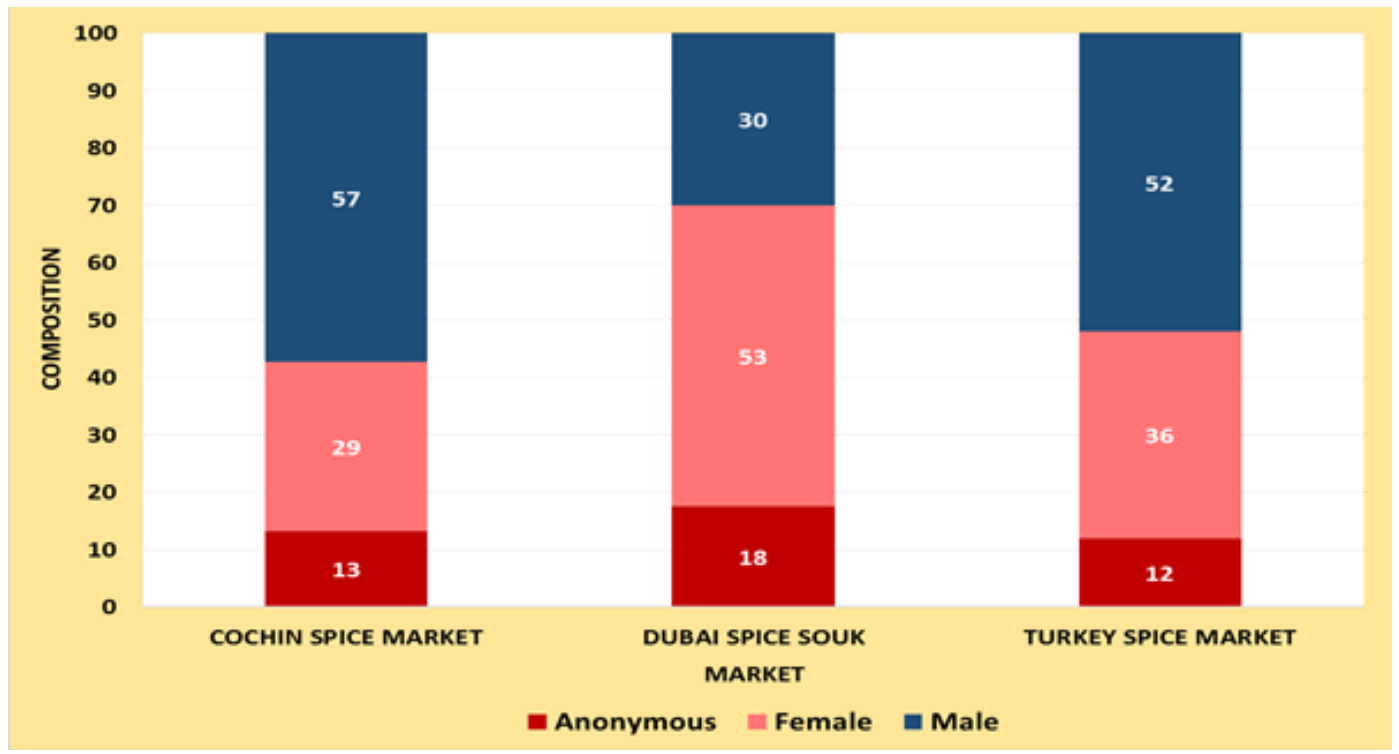

Figure 03. Gender distribution over respective samples

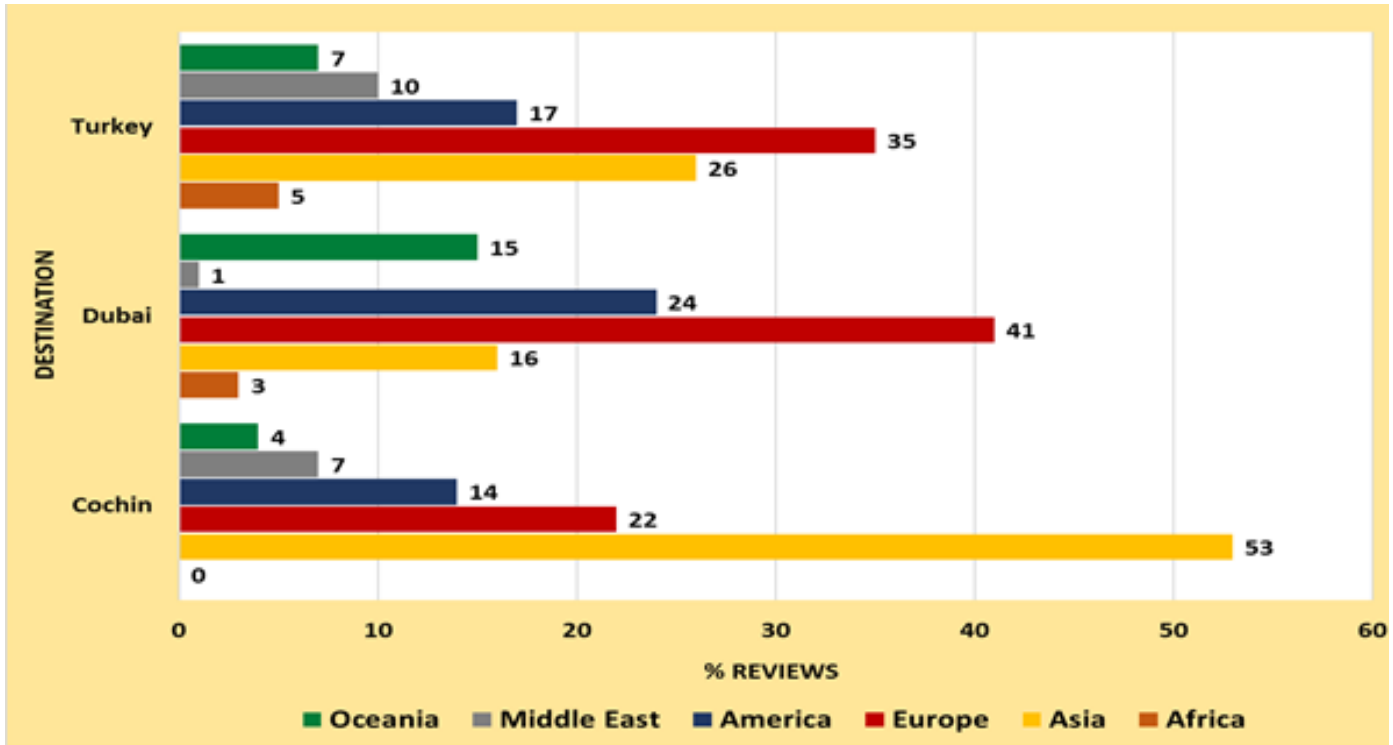

Figure 04. Review distribution by region 
Based on the information published by the TripAdvisorwebsite, reviewers werecategorized into five categories; families, couples, solo, business, and friends, considering the traveling type. The majority of the reviewers who visited the three destinations had traveled as couples and the percentages were recorded as 47,34 , and 37 respectively for Turkey, Dubai, and Cochin spice markets. $28 \%$ and $23 \%$ of reviewers who had been attracted by Dubai and Cochin spice markets had traveled as families. The third-largest proportion of reviewers (16-20\%) were revealed to travel as individual travelers while nearly $13-17 \%$ reported traveling with friends. The proportion of reviewers who had traveled for business purposes constituted $7 \%$, $9 \%$, and $5 \%$ respectively for the three venues. However, this is not in agreement with the findings of Malkanthi and Routray (2012): the majority of the visitors $(56 \%)$ prefer to travel agri-tourism destinations as families. Figure 05 demonstrates a traveler type comparison for the three populations and the respective samples.

\section{Typology of traveler views}

Since, honest, authentic, and comprehensive views published by pro-level travelers could make a significant impact on fellow travelers and travel and tourism-related businesses as opposed to brief and anonymous reviews publish by pre-level reviewers, a "Traveler Review Typology" was developed to analyze the level of reliability associated with the selected reviews which were used to conclude studied spice markets. Based on the data obtained from the "TripCollective" program; an enhanced contributor program that recognizes the contributions of reviewers in each time they contribute to TripAdvisor, reviewers of the selected reviews were categorized into seven different categories as below:

- Travelers who have earned more than 1000 points - as level 6 contributors

- Travelers who have earned 5000 to 9999 points - as level 5 contributors

- Travelers who have earned 2500 to 4999 points - as level 4 contributors

- Travelers who have earned 1000 to 2499 points - as level 3 contributors

- Travelers who have earned 500 to 999 points - as level 2 contributors

- Travelers who have earned 300 to 499 points - as level 1 contributors

- Travelers who have earned 1 to 299 points as primary contributors

As explained in figure 06, every three out of four views included in the samples of Cochin and Dubai spice markets revealed to publish by level $4-6$ contributors; $75 \%$ and $76.1 \%$ respectively. The highest percentage of prolevel views and the lowest percentage of primary views recorded for the Turkey spice market and the respective percentages were calculated as $85 \%$ and $2 \%$. Further, it was identified that only $14.7 \%$ and $13.8 \%$ of the reviews included in the samples for Cochin and Dubai spice souk had been published by primary contributors.

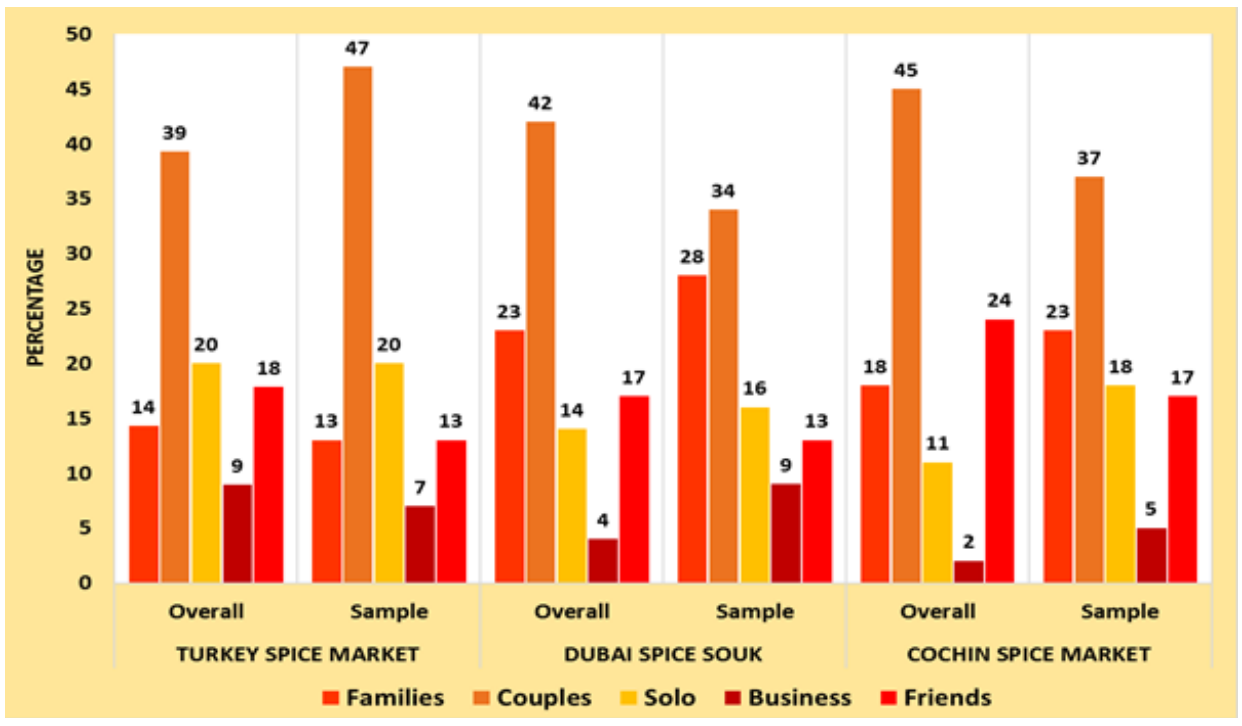

Figure 05. Traveler type comparison 


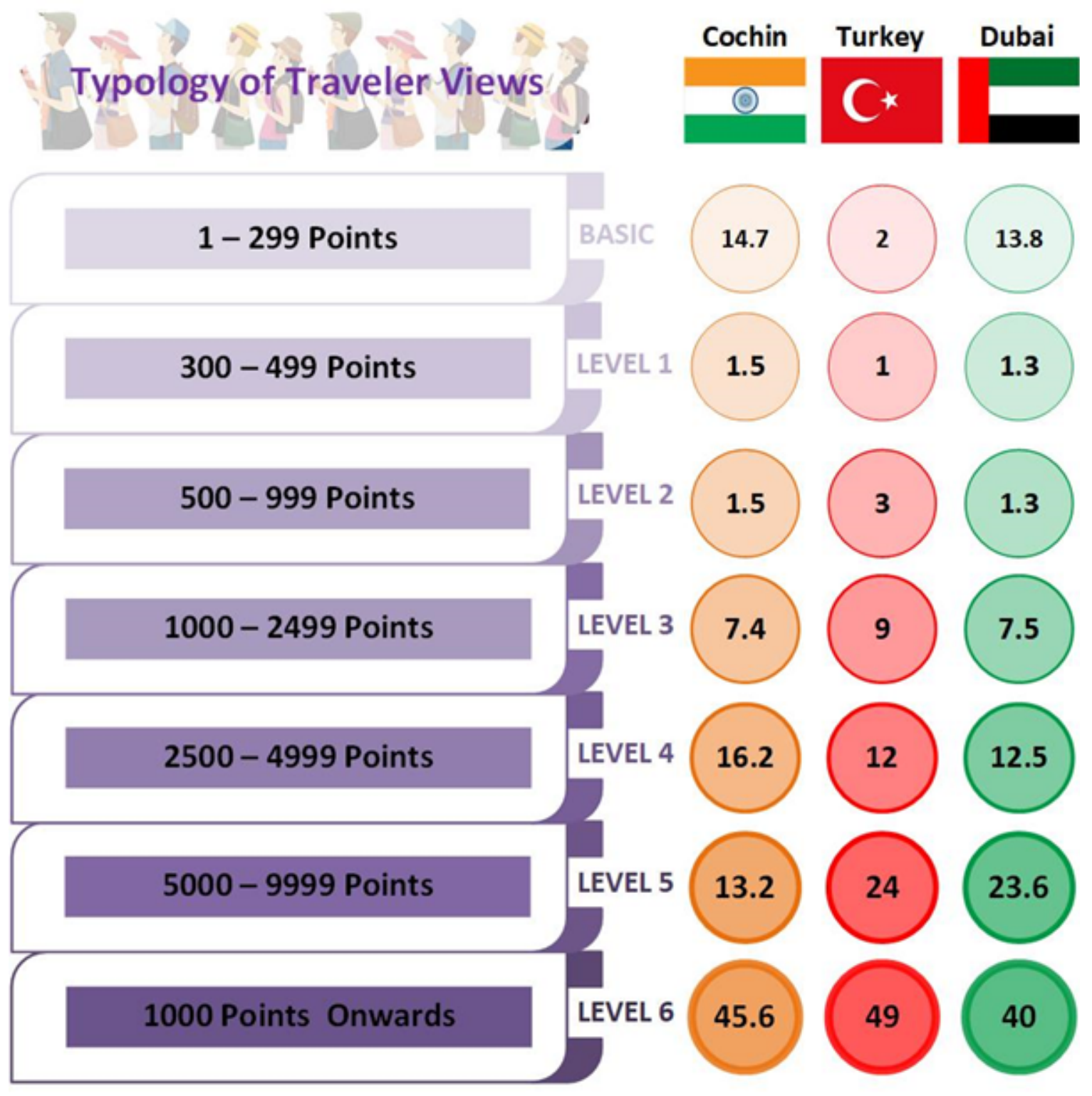

\section{TripCollective Points Guide}

\begin{tabular}{|c|c|c|c|}
\hline Review & 100 points & Rating & 5 points \\
\hline Photo & 30 points & Traveler Article Creation & 100 points \\
\hline Video & 30 points & Traveler Article Edits & 5 points \\
\hline Forum Post & 20 points & Helpful Vote & 1 point \\
\hline
\end{tabular}

Figure 06. Traveler review typology

Source: TripAdvisor TripCollective Overview

The first phase of the study was focused to identify the key strategies adopted by the governing authorities and key actors of the studied spice markets with regard to the marketing mix elements. 
Product Strategies of the Studied Spice Markets

Table 01. Product portfolio of the selected markets

\begin{tabular}{|c|c|c|}
\hline Spice Market & Unique Products & Common Products \\
\hline Cochin Spice Market & $\begin{array}{l}\text { - } \quad \text { Traditional South Indian treats } \\
\text { - } \quad \text { "Rangoli" color powders }\end{array}$ & $\begin{array}{l}\text { Spices } \\
\text { Teas }\end{array}$ \\
\hline Turkey Spice Markets & $\begin{array}{l}\text { - "Farm made" or "farm originated" } \\
\text { cheeses and honey } \\
\text { - } \quad \text { Turkish sujuk and pastirma types } \\
\text { - World-famous Turkish } \\
\text { confectioneries; Turkish delights/ } \\
\text { lokum and variety of Turkish } \\
\text { chocolates } \\
\text { - Different kinds of handmade soap } \\
\text { bars extracted from various plants, } \\
\text { fruits and animal milk }\end{array}$ & $\begin{array}{l}\text { Herbs } \\
\text { Fruits } \\
\text { Essential Oils } \\
\text { Oleoresins } \\
\text { Balms } \\
\text { Textiles } \\
\text { Ceramics } \\
\text { Silk Fabrics } \\
\text { Woven Goods } \\
\text { Embroidered artifacts }\end{array}$ \\
\hline Dubai Spice Souk & 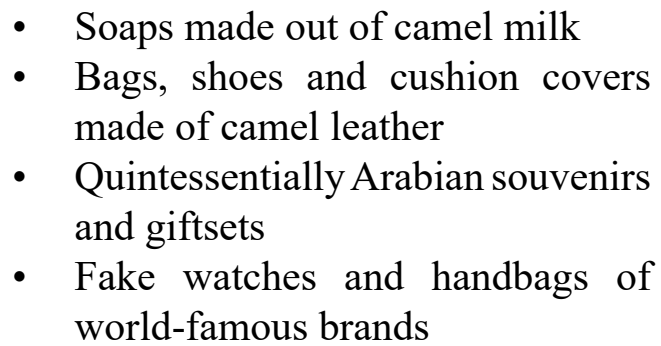 & $\begin{array}{l}\text { Handicrafts and art curios } \\
\text { Cosmetics and ointments } \\
\text { Perfumes and fragrances } \\
\text { Souvenirs and gift items } \\
\text { Household items }\end{array}$ \\
\hline
\end{tabular}

Availability of a wide variety of products ranging from spices to household items was observed as one of the common features in three spice markets. As elaborated in table 01 above, product baskets of the studied markets were revealed to consist of spices originated in South and East Asian regions; whole spices, seed spices, powdered/ground spices, pastes/ concentrates and made-up spice mixes, and wide range of food and non-food products. Yahya (2012) had defined this strategy; market a particular product/product category which is popular among a certain group of customers along with a variety of products that are easily available and affordable by most of the customers, as a marketing paradox used in highly competitive markets to win many customers as possible.

Video documentaries, photo evidence, and traveler views confirmed the availability of herbs, spices, and food products in both packed and loose forms in all three spice markets. Packed spices were found to be marketed mostly under manufacturer labels or private brands and in different size consumer packs ranging from
$50 \mathrm{~g}$ to $1 \mathrm{~kg}$. Malkanthi and Routray (2012) argue, offering spice products in $100 \mathrm{~g}, 250 \mathrm{~g}$, $500 \mathrm{~g}$, and $1 \mathrm{Kg}$ forms is essential in inducing tourists to make purchases. The existence of minimum order quantity (MOQ) rules over the purchases of loose spices was reported only from the Turkey spice market.

Custom printed polythene carrier bags, transparent glass bottles of various sizes and shapes, plastic containers, composite containers, tinplate containers, different types of flexible pouches, lined cartons, and personalized printed carriers were identified as the most commonly used packaging materials at the venues being considered. Only a very few shops in the Cochin spice market and almost all the shops selling spices and food products at the Turkish spice market were found to be equipped with vacuum packing and on-site labeling facilities. Though, no evidence was found to confirm the availability of vacuum packing facilities at the Dubai spice souk, the use of polythene sealers to pack small quantities of spices or herbs was observed in corresponding video documentaries. 
Table 02. Traveler perceptions on product quality in different spice markets

\begin{tabular}{cccc}
\hline & \multicolumn{3}{c}{ Quality of Spices } \\
\cline { 2 - 4 } & $\begin{array}{c}\text { 'Positive' } \\
\text { Perceptions }\end{array}$ & $\begin{array}{c}\text { 'Doubtful' } \\
\text { Perceptions }\end{array}$ & $\begin{array}{c}\text { 'Negative' } \\
\text { Perceptions }\end{array}$ \\
\hline Cochin Spice Market & $80 \%$ & $15 \%$ & $5 \%$ \\
Dubai Spice Souk & - & $33.3 \%$ & $66.7 \%$ \\
Turkey Spice Market & $66.7 \%$ & $16.7 \%$ & $16.7 \%$ \\
\hline
\end{tabular}

Since the product quality plays a significant role either in making or braking consumers' perceptions of products, reviewers' comments published on the quality of the spices available at three venues separately studied. As explained in table 02 , country of origin, freshness, strong taste, alluring odor emanate from spices, and propensity shown by Asian visitors to purchase spices were discovered as key influential factors for the majority of the reviewers to hold positive perceptions on Cochin and Turkey spice markets as reliable sources of high-quality genuine spices. 67 percent of the reviewers had outspoken their displeasure regarding the quality of the spices available at the Dubai spice souk owing to the following reasons; stale/strange odor emanates from spices, old, dusty, and unhygienic appearance of the spices and first-hand experiences of insect infestations and propensity shown by Asian visitors to abstain from purchases of spices. The inability of spice traders to provide necessary certificates (GAP/GMP/Organic/country of origin etc.) or an acceptable evidence to prove the quality and the country of origin, questions over the content of pre-packed spice products, doubts over spice adulteration crated by suspicious behaviors of several spice traders and being exposed to complaints made by ex-travelers via online platforms were identified as key driving forces accountable for the doubtful perceptions held by the rest of the reviewers. In their study "Sustaining production and strengthening the agritourism product", Che et al. (2005) discuss the importance of these four attributes: intrinsic quality, unique packaging, proper labeling, and attractive displaying, in alluring visitor attention towards agri-tourism products.

\section{Price Strategies of the Studied Spice Markets}

Of the sample, 64 percent of the travelers' perceptions of spice prices at the Cochin spice market was revealed to be in the range of "cheap to reasonable" (see table 03 below). Most of the tourists from European and Middle-East regions were found to acknowledge the availability of spices at wholesale rates, comparing the prices of spices at super and hypermarkets in India and their home countries. Approximately, three-fourths of the reviewers (74\%) who had made comments on the Turkey spice market, believed the prices were within the range of "slightly expensive to extremely overpriced even for tourists' standards". The percentage reviews with high price perceptions were recorded as $94 \%$ for Dubai spice souk and most of the travelers had rate the spice prices at the Dubai spice souk as "ridiculous" compared to elsewhere in the Emirates and high-end markets in other countries. Competitive and discount pricing strategies were common to all studied market places. Venders at the Turkey spice market and Dubai spice souk seem to be inclined more towards value-based and premium pricing strategies. Thus, it was well evident that the travelers with high price perceptions were not only stuck the "tourist rip-off" or "tourist trap" label to the respective markets, but also advise potential future visitors to make purchases only from the shops which display an item-wise price list at the entrance. 
Table 03: $\quad$ Traveler perceptions on spice prices in different spice markets

\begin{tabular}{cccc}
\hline & \multicolumn{3}{c}{ Prices of Spices } \\
\cline { 2 - 4 } & $\begin{array}{c}\text { 'Cheap Price' } \\
\text { Perceptions }\end{array}$ & $\begin{array}{c}\text { 'Reasonable Price' } \\
\text { Perceptions }\end{array}$ & $\begin{array}{c}\text { 'High Price' } \\
\text { Perceptions }\end{array}$ \\
\hline Cochin Spice Market & $24.2 \%$ & $39.4 \%$ & $36.4 \%$ \\
Dubai Spice Souk & - & $6.3 \%$ & $93.7 \%$ \\
Turkey Spice Market & $11.8 \%$ & $14.7 \%$ & $73.5 \%$ \\
\hline
\end{tabular}

Place Strategies of the Studied Spice Markets

Discussions held with sales force and distribution partners, revealed that most of the spice shops available at the Cochin spice market were owned and run by Gujarati and Marwari nationals strongly connected with a well-established network of south Indian women cooperatives. Evidence gathered through a comprehensive literature review and corresponding information available in the official website of the Turkey spice market revealed that the spices and herbs being sold in the bazaar are mainly coming through the Egyptian, Indian, Syrian and Arabian marketing channels. It was further explored that certain commercial products; gemstones, jewelries, silk fabrics, woven goods etc., originated in the Italian city-states and Europe reach the Turkey spice market through the local agents of the foreign suppliers. Indian and Iranian traders and entrepreneurs were revealed to pitch their stalls in the Deira district in United Arab Emirates, since way back in 1940s. As a result, India, Iran and Southeast Asian region still remain as the main sources of supply for spices and herbs being traded at the Dubai spice souk, while the rest of the commercial products being supplied by well-established network of foreign suppliers.

Introducing the "expectancy-disconfirmation theory", Richard L. Oliver (1980) posits that expectations coupled with perceived performance lead to "post-purchase satisfaction". It was confirmed by a series of researches in following years; Churchill and Surprenant (1982), Clemons and Woodruff (1992) and Spreng et al. (1996). Based on the argument that the level of post-purchase satisfaction could stimulate consumers to recommend (or to not recommend) a particular experience to others, reviewer perceptions were classified into three different categories to find out the satisfaction levels associated with the spice markets being considered. 66 percent of the reviewers had expressed their willingness to recommend a visit to Cochin spice market not only to buy high-quality genuine spices, but also to enjoy a conventional Indian shopping experience (table 04).

Table 04: Visitors' recommendations for different spice markets

Visitors' Recommendation

\begin{tabular}{cccc}
\cline { 2 - 4 } & $\begin{array}{c}\text { To Buy Spices and } \\
\text { Enjoy Shopping }\end{array}$ & $\begin{array}{c}\text { Not to Buy Spices } \\
\text { but to Experience }\end{array}$ & $\begin{array}{c}\text { Not Recommend a } \\
\text { Visit }\end{array}$ \\
\hline Cochin Spice Market & $65.6 \%$ & $18.8 \%$ & $15.6 \%$ \\
Dubai Spice Souk & $35.2 \%$ & $46.3 \%$ & $18.5 \%$ \\
Turkey Spice Market & $56.3 \%$ & $31.3 \%$ & $12.5 \%$ \\
\hline
\end{tabular}


The percentage of travelers who confidently recommend a visit to Turkey spice market to enjoy an unforgettable Turkish shopping experience was recorded as $56 \%$ and that decision was revealed to be inspired by well organized, quite clean, and completely safe environment prevailed at the market, warm, friendly and helpful staff, availability of all sorts of exotica from around the world under one covered roof, ability to choose from a huge collection of genuine high-quality spices and Turkish sweets, onsite packing and labeling facilities and ability to pay by credit/debit cards. Though nine out of every ten visitors believed the prices of spices were higher than anywhere else in the Emirates and carried negative or doubtful perceptions over the quality of the spices, 35 percent of the reviewers were found to still recommend a visit to the Dubai spice souk (the lowest percentage recorded for all the three venues being considered). Recreational and educational prospects attached with the venues; to learn different uses of various spices and herbs, study different spice blends and seasoning recipes, witness a variety of spices and aromatic herbs coming from different regions of the world in their original forms, capture the aesthetic beauty of stunning architectures (particularly for Turkey and Dubai spice souks), experience the art of trading in different cultures, were discovered as the key motivations for reviewers to recommend visits to spice markets at least for "sightseeing" purposes. Confusions created by huge price variations and poorquality products, immoral behaviors of spice traders, being exposed to better spice markets at home or foreign soils, personal preferences to shop in super or hypermarkets with convenient facilities, were revealed to affect the rest of the reviewers either not to recommend a visit or to propose alternatives to spice markets.

\section{Promotional Strategies of the Studied Spice Markets}

Well planned and attractively designed guided shopping tours offered through licensed tour operators and independent travel guides were identified as the most common promotional strategy adopted by respective authorities of the three spice markets to promote their venues.
The use of digital marketing communication (DMC) tools, open displays of spices (conventional to ultra-modern types), and point of purchase (POP) promotional strategies (catalog marketing, distribution of free samples, product giveaways, and discounted prices) were identified as the prime promotional strategies followed by merchants to unveil various spices to be sold at their venues and to attract more visitors towards their stalls. Promoting the "Fair-Trade Enterprise" concept and the famous visit of Prince Charles and Duchess of Cornwall to the Cochin spice market during their visit to the Mattancherry Dutch palace museum in 2013 were among the unique promotional strategies employed by shop keepers of the Cochin spice market. An elegantly designed, well-maintained, and timely updated website with comprehensive descriptions on touristic services and activities and the extended privilege to the celebrity guests and tourism agents approved by the Ministry of Tourism to reserve the bazaar to enjoy or to offer an exclusive shopping experience was recognized as exclusive promotional strategies adopted by the management of the Turkey spice market to attract high-end clients by whom they could truly generate big revenue. Displaying different symbols (fire tower, a little boat, an ostrich egg, scissor, tassel, etc.) in eaves of the shops was discovered as a micro promotional strategy employed by Turkish shopkeepers to assist potential visitors to easily find the intended shop and give direction to others.

According to Thurlow and Jaworski (2011), in the domain of destination branding, cyber/ virtual spaces encourage users to engage with a destination and turn their momentary, physical location of "self in the place" into an enduring inscription. It was further confirmed by Buhails and Wagner (2013): "a destination develops its unique brand using these special platforms to build trust, stay competitive in the market, manage its online reputation and deploy all its features and attributes". This phenomenon inspired us to study the use of "Digital Marketing Communication Platforms" by the studied destinations. As elaborated in figure 07, social media tools, mobile marketing, online ads/videos, display ads, microsites, online 


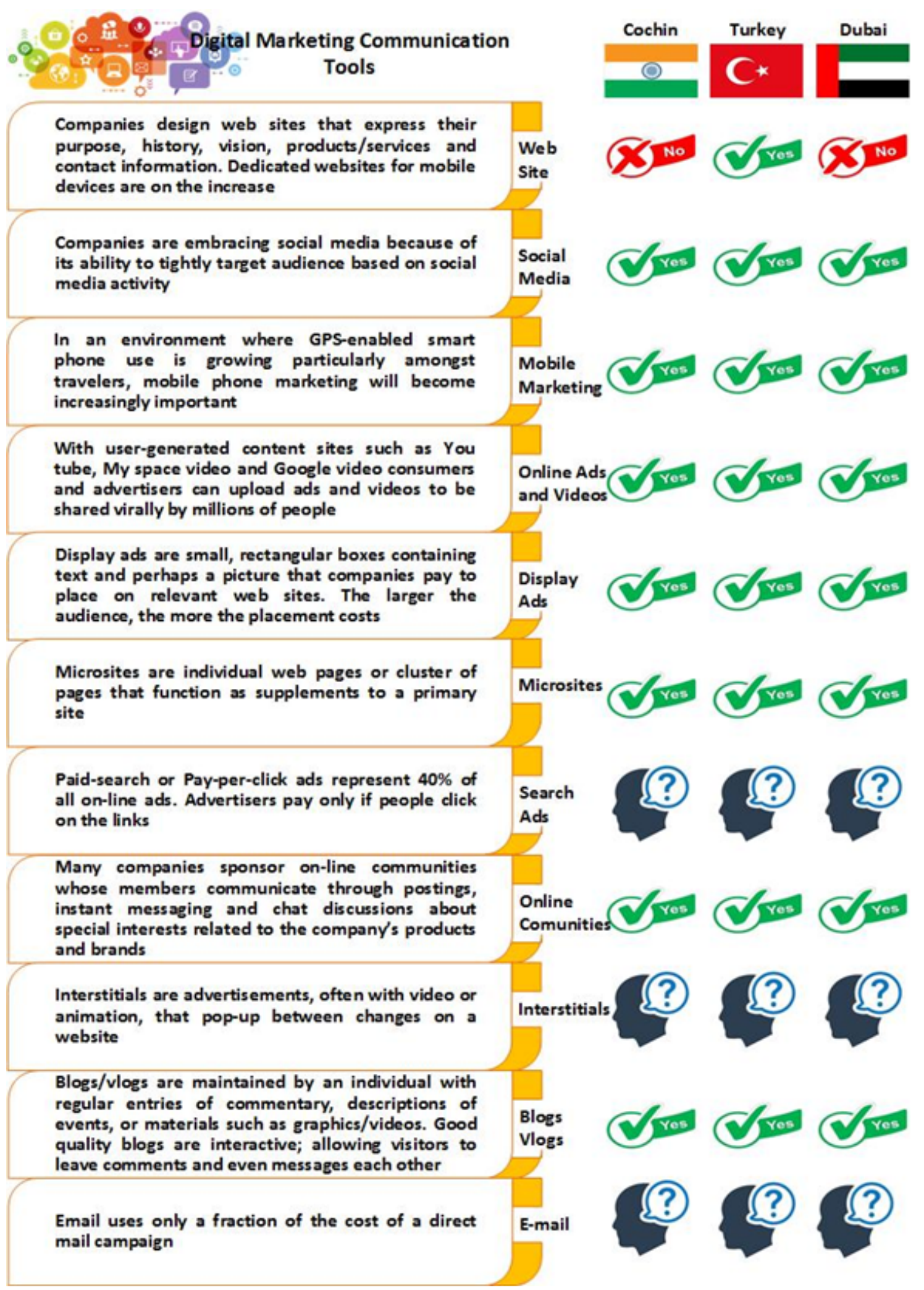

Figure 07. DMC tools being used to promote studied destinations

communities, blogs and vlogs were identified as most commonly used ICT tools across the markets. Turkey spice market was identified as the only destination to host its own web site. No solid evidences were found to confirm the use of search ads, interstitials and e-mails as micro promotional tools.
Since "human factor" plays an important role in achieving effectiveness, competitiveness, success, and profitability in any business establishment, reviewers' perceptions regarding the "people" component were separately evaluated particularly to identify the strengths and the weaknesses of the individuals who 
directly or indirectly involved with the activities of considered spice markets (Table 05). Results revealed that almost all the reviewers of the Cochin spice market and 62 percent of the reviewers of the Turkey spice market were pleased with the way that the shop owners, managers, receptionists, sales representatives, and brokers interact with them. Ability to speak multiple languages including English, product awareness, willingness to respond to customer queries, preparedness to assist customers to meet their needs, the enthusiasm showed when assisting customers coupled with virtues such as honesty, kindness, patience, calmness, friendliness, respectfulness, were among the highly acknowledged behavioral characteristics. The majority of the reviewers $(77 \%)$ commented on Dubai spice souk were revealed to express their discontent about the aggressive, assertive, stubborn, pushy, greedy, annoying, rude, and wild behaviors shown by several shop keepers and sales assistants throughout their constantly struggling missions to attract more customers over their competitors. Such vices had not only frustrated the visitors but also made them publish harsh comments on spice merchants via online platforms (such as "thieves who were just looking to steal from tourists" or "morons from the the12th century who don't deserve any business") simply spoiling the hard-earned good name and reputation of the disciplined salesforce partners. This is in line with the argument presented by Amoah and Baum (1997), by which they contend that all the interactions between the tourists and the employees employed in the industry are crucial in 'making or breaking the tourist experience'.

Factors associated with willingness to visit spice markets, purchase spices/non-spice products, and enjoy spice-based services

Based on the descriptive analysis, the research identified three socio-economic attributes; a) gender, b) region, and c) traveler type, that could associate with the willingness of tourists to visit spice markets, purchase spices/non-spice products, and enjoy spice-based services. The identified attributes were tested using the Chisquare test at the 95 percent confidence interval.

Table 05: Visitor perceptions on sales staffs in different spice markets

\section{Perceptions on Sales Staff}

\begin{tabular}{ccc}
\cline { 2 - 3 } & $\begin{array}{c}\text { 'Positive' } \\
\text { Perceptions }\end{array}$ & $\begin{array}{c}\text { 'Negative' } \\
\text { Perceptions }\end{array}$ \\
\hline Cochin Spice Market & $100 \%$ & - \\
Dubai Spice Souk & $23.3 \%$ & $76.7 \%$ \\
Turkey Spice Market & $62.1 \%$ & $37.9 \%$ \\
\hline
\end{tabular}

Table 06: Factors associated with willingness to visit spice markets, purchase spices/ non-spice products, and enjoy spice-based services

\begin{tabular}{cccc}
\hline Factor & $\begin{array}{c}\text { Willingness to } \\
\text { visit spice markets }\end{array}$ & $\begin{array}{c}\text { Willingness to } \\
\text { purchase spice/non- } \\
\text { spice products }\end{array}$ & $\begin{array}{c}\text { Willingness to enjoy } \\
\text { spice-based services }\end{array}$ \\
\cline { 2 - 4 } & P value & P value & P value \\
\hline Gender & 0.152 & 0.326 & 0.315 \\
Region & $0.003^{*}$ & $0.027^{*}$ & $0.023^{*}$ \\
Traveler type & $0.001^{*}$ & $0.038^{*}$ & $0.021^{*}$ \\
\hline
\end{tabular}

*Significant at 95\% Confidence Interval 
According to the findings, two out of the three studied attributes; region and traveler type, showed significant positive associations with the willingness of tourists to visit spice markets, purchase spices/non-spice products, and enjoy spice-based services (Table 06). This is partially in line with the findings of Malkanthi and Routray (2012), where they had identified significant associations with the living area of visitors and their willingness to visit agritourism destinations and purchase spice products. Further, both studies confirm the fact that there is no significant association between the gender of the tourists and their involvement in spice tourism.

\section{Selection of the Location for the Proposed Spice Market/s}

The second objective of the study was to select an appropriate location for the proposed spice market. Yu Chou et al., (2008) argue that the selection of a facility location has important strategic implications since allocation decisions normally involve a long-term commitment of resources. It had been confirmed by Yang and Lee (1997); location is a significant factor influencing the operational performance. The most ideal locations for the proposed spice market were selected based on three criteria; tourist traffic from top ten source markets, guest nights (both foreign and local) in graded accommodation establishments, and spice growing regions in Sri Lanka. 2017 was taken as the base year and the relevant statistics were obtained from the Annual Statistical Reports of Sri Lanka Tourism Development Authority (SLTDA) and Department of Export Agriculture.

According to the tourist travel information generated by the Electronic Travel Authorization System (ETA) compiled by the Department of Immigration and Emigration, India, China, United Kingdom, Germany, France, Australia, Maldives, Russia, USA, and Canada were the ten main tourist markets accountable for the highest tourist traffic to the country for the year under review. Most interestingly, all the ten destinations were revealed to hold mid to high size markets for spices and seasonings (Mordor
Intelligence, 2017).

The highest number of "guest night/s"; night/s spent by local and foreign visitors in SLTDA approved accommodation establishments, were recorded from the South Coast region of the country. Accordingly, graded accommodation establishments located in the south coast region were revealed to host 4,757,605 guest nights during the period of consideration while Colombo city, Greater Colombo region, hill country, and ancient cities hosting 3,032,581, $1,886,260,742,255$ and 1,348,162 guest nights respectively. As precisely identified by the most prominent Sri Lankan spice concentrate around the intermediate and wet zones of the country, it is revealed; cinnamon in low and up-country wet zones, cardamom in the up-country wet zone, mid and up-country intermediate zones, pepper, cloves, nutmeg and mace in up and mid-country wet zones.

Considered criteria were superimposed to identify the best region/s to establish the proposed spice market. Ideal locations with required potentials were then selected taking the expertise of the key industry stakeholders into account. Accordingly, Bentota, Hikkaduwa, and Galle; three popular seaside resort towns in Southwestern Sri Lanka, and Kandy; world famous tourist destination in Central hills were recognized as the best locations for the intended purpose (see figure 08).

The proposed locations are supposed to play a significant role not only from the business' point of view; to promote the facility, attract visitors, suppliers, and service providers, encourage repeat visits, create an elite group of loyal customers, earn a competitive advantage over the competing spice markets in the region, shorten the payoff period for the fixed capital investments and to achieve maximum returns on the investment, but also from customers'/ consumers' point of view; to reduce visitors' cost of seeking new tourist attractions, and to reduce visitors' friction to tour isolated sites. 

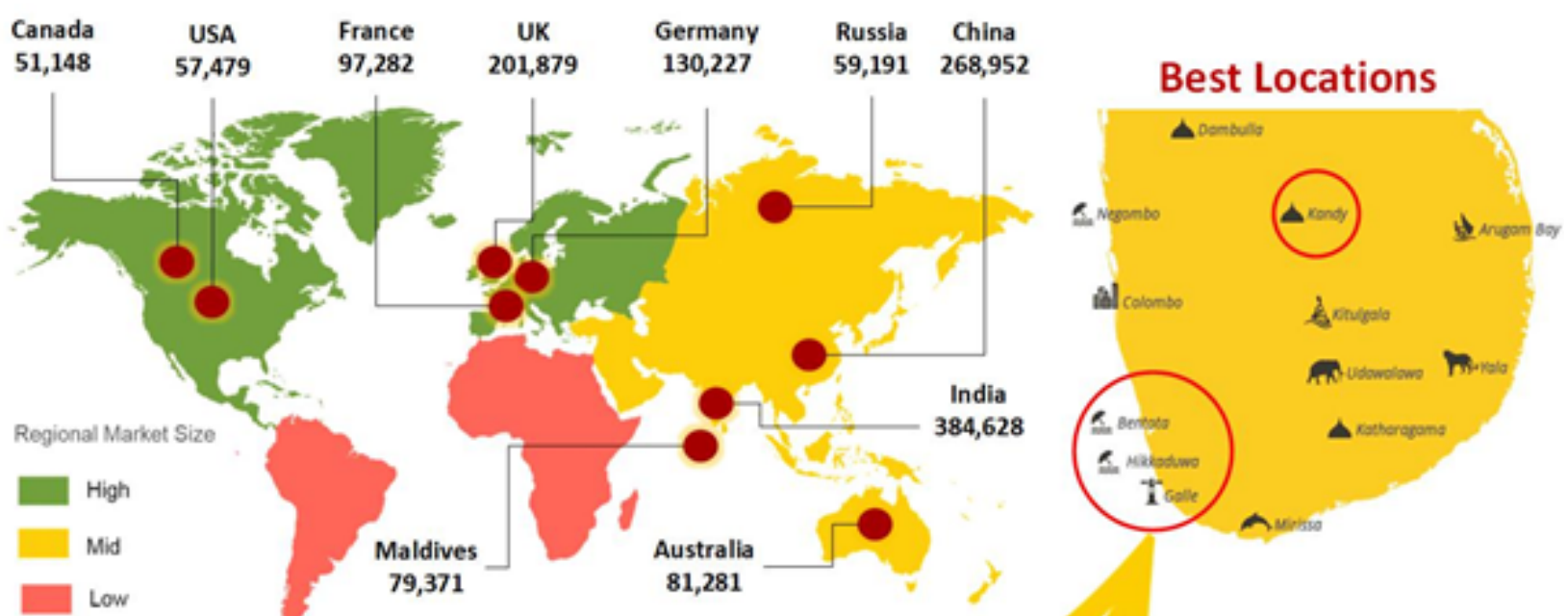

Global Spice \& Seasoning Market Vs Top Ten Tourist Markets (2017)
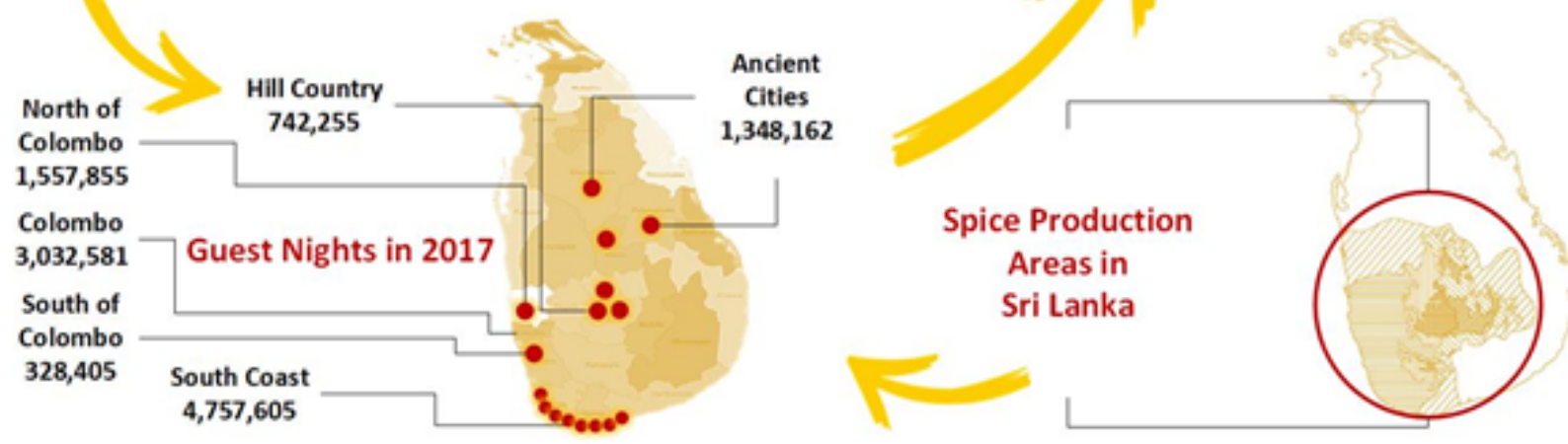

Figure 08. Systematic process employed to select the best locations for the spice market

Table 07: Proposed guidelines and strategies to establish a "Ceylon Spice Market"

\begin{tabular}{|c|c|c|}
\hline & Aspect & Proposed strategy/s \\
\hline \multirow[t]{3}{*}{$\begin{array}{l}\text { Prod- } \\
\text { uct }\end{array}$} & Variety & $\begin{array}{l}\text { - It is proposed to give top priority to; traditional Sri Lankan spices, } \\
\text { spice related products, spice related services and processors. } \\
\text { Further, it is proposed to accommodate following products } \\
\text { categories to attract non-spice lovers and excursionists; handloom } \\
\text { textiles and clothing, gem and jewelry, beverages, bakery products, } \\
\text { Sri Lankan cuisines, traditional Sri Lankan desserts and sweets }\end{array}$ \\
\hline & Quality & $\begin{array}{l}\text { - When allotting shopping spaces and renewing licenses, priority } \\
\text { should be given to the spice producers and processors armed } \\
\text { with product/process certifications; Organic, SLGAP, SLS, } \\
\text { GMP, HACCP, ISO, FSSC, BRC, Kosher etc., and/or voluntary } \\
\text { standards; Fairtrade, Rainforest for their offerings }\end{array}$ \\
\hline & Packaging & $\begin{array}{l}\text { - Spices traders and suppliers should be encouraged to select food } \\
\text { grade packing materials } \\
\text { - Higher attention should be paid to product labeling; special features } \\
\text { and uses of Ceylon spices should be highlighted in most spoken } \\
\text { international languages such as English, Spanish and Arabic } \\
\text { - Products should make "traceable" through the inclusion of } \\
\text { "product identification tags" in labels }\end{array}$ \\
\hline
\end{tabular}




\begin{tabular}{|c|c|c|}
\hline & Aspect & Proposed strategy/s \\
\hline Price & & $\begin{array}{l}\text { - Laws/recommendations should establish to display an item vise } \\
\text { price list in US dollar terms at the entrance of each shop and shop } \\
\text { keepers should be encouraged to accept cash (rupee and dollar } \\
\text { payments) and card payments (Visa and/or MasterCard) } \\
\text { - Visitors should be encouraged to purchase only from shops which } \\
\text { display price lists to avoid being hassled by the vendors }\end{array}$ \\
\hline \multirow[t]{2}{*}{ Place } & $\begin{array}{l}\text { Marketing } \\
\text { Channels }\end{array}$ & $\begin{array}{l}\text { - Spice traders and suppliers should be encouraged to purchase } \\
\text { spices and spice related products (at least a certain share) from } \\
\text { Spice Producer's Societies (SPS) and women cooperatives } \\
\text { whenever possible }\end{array}$ \\
\hline & $\begin{array}{l}\text { Facilities and } \\
\text { Management }\end{array}$ & $\begin{array}{l}\text { - Local government authorities are supposed to set up all the } \\
\text { required facilities not only for visitors; information desks, ATM } \\
\text { machines and/or money exchange counters, food court, kids play } \\
\text { area, free wi-fi facility, passenger elevators, wash room facilities, } \\
\text { emergency exits, relaxing outdoor seating arrangements, parking } \\
\text { slots etc., but also for spice traders and suppliers; electricity, water } \\
\text { supply, telephone and internet connections, fire sprinklers, pull- } \\
\text { down shutters, freight elevators, a weigh bridge, unloading slots, } \\
\text { spice/goods warehouse etc. } \\
\text { Maintenance and safekeeping functions should be handed over } \\
\text { to facility management services providers and security solutions } \\
\text { providers on contract basis }\end{array}$ \\
\hline & Promotion & $\begin{array}{l}\text { - It is proposed to design an inspiring, creative and well-maintained } \\
\text { comprehensive website } \\
\text { - Promotional campaigns should be organized in collaboration with } \\
\text { respective authorities and partners under the slogan "No visit to } \\
\text { Sri Lanka is complete without a stopping at atmospheric spice } \\
\text { market" } \\
\text { - Famous bloggers and vloggers should be invited to write inspiring } \\
\text { articles and to produce video documentaries to be published in top } \\
\text { rated tourism blogs and vlogs } \\
\text { - Privilege should be extended to tourism agents approved by the } \\
\text { Ministry to reserve the spice market, to offer an exclusive shopping } \\
\text { experience to their high-end clientele } \\
\text { - Spice traders should be given the freedom to use point of purchase } \\
\text { promotional strategies in a constructive way without disturbing } \\
\text { the peaceful environment of the market }\end{array}$ \\
\hline & People & $\begin{array}{l}\text { - Shop owners should be encouraged to employ bilingual or } \\
\text { multilingual individuals as employees } \\
\text { "Code of conduct" should be developed as an effective means to } \\
\text { discourage any participant from conducting themselves improperly } \\
\text { or in a manner that is contrary to the norms of the spice market }\end{array}$ \\
\hline
\end{tabular}


Table 07 summarizes the proposed guidelines and strategies developed to fulfill the requirements of the final phase of the study, to carry the spice market concept forward within the Sri Lankan context.

\section{CONCLUSION}

Based on the travelers' perceptions towards the spice markets and their willingness to engage in spice market activities, it can be concluded that there would be a considerable demand for spice market establishment/s. The highest demand for the proposed establishment/s would be from Asian, European, and American travelers. The majority of the travelers would visit the establishment as couples, families, and individual travelers, not only to buy spices/nonspice products and enjoy spice-based services, but also to experience the recreational and educational prospects attached with the venue. The study found clear evidence to the fact that the product, price, place, promotion, physical evidence, and people factors could make a significant impact on the level of satisfaction of the tourists/travelers. Hence, the success and profitability of the proposed establishment is expected to depend on both the visitor count and their level of satisfaction. Therefore, this study proposes to incorporate cultural, educational, recreational, and wellness activities into the spice tourism to make the segment more attractive for the potential visitors. The enormous potential to offer superior quality spices and spice related value-added products for reasonable prices coupled with the worldfamous Sri Lankan hospitality would provide Sri Lanka a competitive edge over the other countries in this regard. Harmonizing the interests of the different stakeholders of the tourism and spice industries will be key to develop unorthodox strategies to guide the spice market concept to its zenith within the cultural, economic, and environmental framework of Sri Lanka. If implemented in a planned way, the proposed model would generate thousands of employment opportunities and novel income sources for all the parties involved while delivering a momentous contribution to the country's socio-economic development.

\section{DATA AVAILABILITY STATEMENT}

The datasets generated during and/or analyzed during the current study are available from the corresponding author on reasonable request.

\section{ACKNOWLEDGEMENT}

The authors are thankful to the National Science Foundation and the Ministry of Primary Industries for financial assistance (SP/CIN/2016/05) and the Sabaragamuwa University of Sri Lanka for administrative assistance.

\section{REFERENCES}

Amoah, V., and Baum, T. (1997). Tourism education: policy versus practice. International Journal of Contemporary Hospitality Management, Vol. 9, 5-12.

Bandara, T.D. (2016). Determinants of Tourist Satisfaction with Agro Tourism: The Case of Spice Gardens in the Central Province of Sri Lanka. NSBM Students' Research Symposium, Colombo, Sri Lanka. URL: https://docplayer.net/26800486-Nsbm-students-researchsymposium-extended-abstracts-march-4-2016-national-school-of-business-managementcolombo-5-sri-lanka.html

Barbieri, C. (2010). An importance-performance analysis of the motivations behind agritourism and other farm enterprise developments in Canada. J. Rural Community Develop., 5(1-2), $1-20$.

Buhalis, D., and Wagner, R. (2013). E-destinations: Global best practice in tourism technologies and application. In L. Cantoni \& X. Xiang (Eds.), Information and Communication Technologies 
in Tourism, Vienna (pp. 119-130). Springer Verlag.

Central Bank of Sri Lanka. (2018). Annual report, Central Bank of Sri Lanka.

Che, D., Veeck A., and Veeck G. (2005). Sustaining production and strengthening the agritourism product: Linkages among Michigan agritourism destinations. Agric. Human Values, 22, 225234.

Chou, T.-Y., Hsu, C.-L., Chen, M.-C. (2008). A fuzzy multi-criteria decision model for international tourist hotels location selection. International Journal of Hospitality Management, 27(2), 293-301.

Churchill, G.A. (Jr), and Surprenant, C. (1982). An investigation into the determinants of customer satisfaction. Journal of Marketing Research, Vol. 4, 491-504.

Clemons, D.S. and Woodruff, R.B. (1992). Broadening the view of consumer (dis) satisfaction: a proposed means-end disconfirmation model of CS/D. American Marketing Association, Winter (pp. 413-421).

Global Seasonings and Spices Market Report (2019). Zion Market Research. https://www. globenewswire.com/Index

González, S., Bulchand-Gidumal, J., and López-Valcárcel, B. G. (2013). Online customer reviews of hotels as participation increases, better evaluation is obtained. Cornell Hospitality Quarterly, 54(3), 274-283.

Hall, R. (2011, September 13). TripAdvisor removes its 'reviews you can trust' slogan. The Independent. https://www.independent.co.uk/travel/news-and-advice/tripadvisor-removesits-reviews-you-trust-slogan-2353669.html.

Hettiarachchi, I.C., De Silva, D.A.M., Esham, M., Liyanagamage, T.M., Abeysinghe, A.M.I.P., Warnakulasooriya, S., Harindra, W.A.M. (2020). An Assessment of Market Landscape of Cinnamon in Sri Lanka. The Journal of Agricultural Sciences - Sri Lanka, 15(2), 181-189. http://doi.org/10.4038/jas

Huang, Y., Basu, C., and Hsu, M. K. (2010). Exploring motivations of travel knowledge sharing on social network sites: an empirical investigation of U.S. college students. Journal of Hospitality Marketing \& Management, 19(7), 717-734.

Hudson, S., and Thal, K. (2013). The Impact of Social Media on the Consumer Decision Process: Implications for Tourism Marketing. Journal of Travel \& Tourism Marketing, 30(1-2), 156160. DOI: $10.1080 / 10548408.2013 .751276$

Mac-Intosh, E. F. (2011). Spice gardens of Sri Lanka. http://thespicejournal.com/about-spice-srilanka/spice-gardens-of-sri-lanka/

Mahaliyanaarachchi, R.P. (2016). Agri Tourism as a Risk Management Strategy in Rural Agriculture Sector: with Special Reference to Developing Countries. Journal of Agricultural Sciences, 11(01), 1-12.

Manente, M. and Minghetti, V. (2006). Destination Management Organizations and Actors. 
(in) Tourism Business Frontier, D. Buhalis, C. Costa (Eds2q.) Tourism Business Frontier.(pp. 229-230), Elsevier.

Manente, M. and Minghetti, V. (2006). Destination Management Organizations and Actors. (in) Tourism Business Frontier, D. Buhalis, C. Costa (ed.). (pp. 229-230), Elsevier.

Malkanthi, S.H.P. and Routray, J. K. (2012). Visitor satisfaction in agritourism. International J. Agric. Manage., 2(1), 30.

Malkanthi, S.H.P. (2017). Potential visitors of spice tourism and their intended future behavior. Sri Lanka Journal of Food and Agriculture, 3(1), 19-28.

Manente, M. and Minghetti, V. (2006). Destination Management Organizations and Actors. In D. Buhalis, and C. Costa (Eds.), Tourism Business Frontier, (pp. 229-230). Elsevier.

Mate, J., Trupp, A., and Pratt, S. (2019). Managing negative online accommodation reviews: evidence from the Cook Islands. Journal of Travel \& Tourism Marketing, 36(5), 627-644. DOI: $10.1080 / 10548408.2019 .1612823$

Mordor Intelligence. (2017). Industry Report on Global Seasoning and Spices Market-Growth, Trends, and Forecast, Mordor Intelligence LLP.

Ndou, V., and Claudio, P. (2007). DMS Business Models Design and Destination Configurations: Choice and Implementation Issues. Journal of IT \& Tourism, 3-14.

Oliver, R. L. (1980). A cognitive model for the antecedents and consequences of satisfaction decisions. Journal of Marketing Research, 27, 460-69.

Prabhudesai, S. and Kunde, S. (2011, November). ICT in AgroTourism: A case study of Pascoal Organic Spice village, Goa. IJCA Proc. Third Annual Global Business: IT and Management for Economic Development Conference, India.

SAPPTA. (2015). Annual Report, The Spices and Allied Products Producers' and Traders' Association, Sri Lanka.

Schilling, B., Sullivan, K. and Komar, S. (2012). Examining the economic benefits of agritourism: The case of New Jersey. J. Agric, Food Syst, 3(1), 199-214.

Sri Lanka Export Development Board. (2017). Annual report, Sri Lanka Export Development Board.

Sri Lanka Tourism Development Authority. (2018). Annual Statistical Report, Sri Lanka Tourism Development Authority.

Spreng, R. A., Mackenzie, S. B., \& Olshavsky, R. W. (1996). A re-examination of the determinants of consumer satisfaction. Journal of Marketing, Vol. 60, 15-32.

Thurlow, C., and Jaworski, A. (2011). Tourism discourse: Languages and banal globalization. Review of Applied Linguistics, Vol. 2, 285-312.

Yahya, A. (2012). Paradox marketing: unusual way to win. Jakarta: Gramedia Pustaka Utama. 
Yang, J., and Lee, H. (1997). An AHP decision model for facility location selection. Facilities, $15(9 / 10), 241-254$.

Stagg, J., (2011, November 10). Caterer and Hotelkeeper interview - Christine Petersen, TripAdvisor. The Caterer. https:/www.thecaterer.com/news/hotel/caterer-and-hotelkeeperinterview-christine-petersen-tripadvisor

Xie, K., Chen, C., and Wu, S. (2016). Online Consumer Review Factors Affecting Offline Hotel Popularity: Evidence from Tripadvisor. Journal of Travel \& Tourism Marketing, 33(2), 211223. DOI: $10.1080 / 10548408.2015 .1050538$

Zhang, Y., and Vásquez, C. (2014). Hotels' responses to online reviews: Managing consumer dissatisfaction. Discourse, Context \& Media, Vol 6, 54-64. 